\title{
Friendship in a time of protest? Friedrich Schleiermacher and Russel Botman on the fabric of (civic) friendship
}

\begin{abstract}
Author:
Nadia Marais ${ }^{1}$ (D)

Affiliation:

${ }^{1}$ Department of Systematic

Theology and Ecclesiology,

Faculty of Theology,

Stellenbosch University,

Cape Town, South Africa

Corresponding author:

Nadia Marais,

nadiam@sun.ac.za

Dates:

Received: 30 May 2019

Accepted: 05 July 2019

Published: 19 Nov. 2019
\end{abstract}

How to cite this article:

Marais, N., 2019, 'Friendship

in a time of protest? Friedrich

Schleiermacher and Russel

Botman on the fabric of (civic)

friendship', HTS Teologiese

Studies/Theological Studies

75(3), a5592. https://doi.org/

10.4102/hts.v75i3.5592

Copyright:

(c) 2019. The Authors. Licensee: AOSIS. This work

is licensed under the

Creative Commons

Attribution License.

Read online:

Scan this QR code with you smart phone or mobile device to read online.
Friendship is not often associated with citizenship, politics or civil society - and yet this contribution proposes that civic friendship(s) may be worth consideration as an expression of peacemaking and peacebuilding: the dynamic interplay between our 'social' and 'individual' selves working towards peace and countering violence. This theological consideration of friendship deals with the interaction between individuality and sociability in the work and thought of a theologian who was deeply interested in such interplay and which may therefore be helpful in theological reflection on friendship. This contribution draws on two theologians who were involved in higher education themselves - the German theologian Friedrich Schleiermacher, who served as rector of the Humboldt University of Berlin (1815-1816), and the South African theologian Russel Botman, who served as rector of Stellenbosch University (2007-2014) - from whom we may learn about (civic) friendship.

Keywords: friendship; peacemaking; Russel Botman; Friedrich Schleiermacher; higher education.

\section{Introduction}

While in tyrannies friendship and justice hardly exist, in democracies they exist more fully; for where citizens are equal they have much in common.

(Aristotle 2009:157; 1161b8-1161b10)

South African civil life is not altogether unfamiliar with protests or with the dissatisfaction of communities with a series of interrelated issues. Service delivery protests, protests for wage increases and protests against corruption within government take place regularly, and have become part of a South African civic language aimed at addressing injustice, inequality and corruption. Protest therefore continues to be a part of everyday civic life in democratic South Africa, so that the time of protest to which the title of this contribution alludes should not create the wrongful expression that protest is somehow alien to South African civil society.

However, what has been creating a new dynamic within a society familiar with protest has been the rise of the \#mustfall movement and \#fallist student leaders. When sporadic protests at university campuses in 2015 swelled into a nationwide protest, South African civil society supported students' resistance of the annual increase in university fees and the call for free tertiary education. A number of related issues would come to be addressed in this time, such as violence against women on campus (\#endrapeculture), the permanent employment of support staff (\#endoutsourcing) and the decolonisation of curricula.

I sketch this picture in broad strokes, with no intention of attempting to describe all of the intricate dynamics and complicated politics that accompany any talk of the \#feesmustfall protests, to make only one point, namely, that theological reflection on friendship cannot be disembedded from protest(s) in South Africa, and particularly protests in higher education, because civic friendship is itself a form of participating in civic power dynamics and patterns. What is worth noting with regard to the \#mustfall protests, however, is that these protests - which claim to stand in the historical trajectory of Sharpeville (1960) and the Soweto uprising (1976) - are shaping the texture

Note: This paper was presented at the Schleiermacher Group of the American Academy of Religion in San Antonio (19-22 November 2016), with the theme 'Networks of Becoming: Individuality, Friendship, and Forms of Social Life.' It is at this meeting of the AAR that first met Eben Scheffler, and enjoyed drinking a beer with him and Alphonso Groenewald. I thought it fitting - poetic, even! - that this exact paper (presented at this same AAR meeting where I met Eben, and which happened to deal with the theme of friendship), should go toward Eben's festschrift, as a way of saying thank you for his life and work as a theologian and a friend. So, thank you, Eben - for your friendship. Here's to many more years and beers!

The collection entitled 'Eben Scheffler Festschrift', sub-edited by Jurie H. le Roux (University of Pretoria) and Christo Lombaard (University of South Africa). 
of South African society in institutions of higher education (including in departments and faculties of theology), ${ }^{1}$ and are challenging the entire system of higher education in South Africa. Indeed, it is not merely internal reform that students have in mind, but an extensive, broad, deep transformation of university communities. ${ }^{2}$

Herein, and prior to \#feesmustfall, a number of initiatives were and are aimed at developing thought leaders for South Africa and Africa. In this contribution, two such initiatives are invoked - the Listen, Live and Learn Houses at Stellenbosch University and the Mandela Rhodes Scholarships - that both focus on creating a network of thought leaders who, within communities (houses and cohorts, respectively), are trained and challenged to help shape and reshape South African civil society. The purpose of invoking two examples of networks wherein civic friendships are fostered is to illustrate the small but important potential of friendship for building, making and maintaining the kind of peace that is concerned about the flourishing and wellbeing of fellow citizens.

Friendship - and particularly civic friendship or friendship in civil society - may yet have an important role to play, as an expression of the interplay between individuality and sociability in public life. Arguably, it is from two theologians who were themselves involved in higher education - the German theologian Friedrich Schleiermacher, who served as rector of the Humboldt University of Berlin (1815-1816), and the South African theologian Russel Botman, who served as rector of Stellenbosch University (2007-2014) - that we may learn something of the potential of (civic) friendship as a social strategy.

\section{Friendship as social strategy}

In his last opening speech of the Parliament of South Africa (in 1999), former president Nelson Mandela would conclude that South African society needs 'an RDP of the soul' because 'there is something wrong' with a society where freedom is not qualified by responsibility (Botman 2004:513). This would publicly be described as 'a crisis of the moral fibre' of society in South Africa - a crisis that would require a reconsideration of 'the social foundation of society' and the partnerships that make sociability possible (Botman 2004:513). Herein friendship, and more particularly civic friendship, may become a social strategy to shape the common good and work towards the well-being of fellow citizens.

A prominent South African scholarship programme that aims to shape and produce thought leaders capable of such

1.See in this regard the excellent respective publications by the American Reformed theologian David H. Kelsey, entitled 'Theology in the University: Once more, with feeling' (2009), and Irish Anglican theologian David F. Ford, entitled 'The future of theology at a public university' (2017).

2.I have explored the rhetoric of transformation in an as yet unpublished pape presented at the Nuremberg Forum in Germany (02-06 October 2016), with the title 'A theological appraisal of the ' $T$ '-word: Russel Botman, Stellenbosch University, and the rhetoric of transformation'. Former rector and theologian Russel Botman wrote his doctoral dissertation on a theology of transformation (entitled wrote his doctoral dissertation on a theology of transformation (entitled
'Transformation as Discipleship? Towards a Theology of Transformation'), at the 'Transformation as Discipleship? Towards a Theology of Transforma
University of the Western Cape (completed 1993) (cf. Botman 1993). friendship is the Mandela Rhodes Scholarships (so-called for its benefactors, Nelson Mandela and Cecil John Rhodes), wherein students are grouped into 'cohorts' and by way of four concerns: reconciliation, education, entrepreneurship and leadership. These scholars are chosen from various African countries and become part of the Mandela Rhodes Community upon completion of their year-in-residence, whereafter they form part of a network of young leaders in Africa. This community is shaped (among other things) by the concern for equal citizenship among all human beings, 'the advancement of individual and social fulfillment', and aspirations for the formation of a society 'in which we are all each other's keepers' ${ }^{3}$ Individual and social formation is, in other words, a negotiated interplay within this community of thought leaders, and herein friendship becomes an important strategy for simultaneously holding together a duty to the common good and a commitment to the flourishing of fellow citizens.

So too the late rector and vice chancellor of Stellenbosch University, Russel Botman, regarded friendship as a key social strategy to address stereotyping among students and student leaders, and consequently established the LLL initiative (Listening, Living, Learning) at Stellenbosch University to this end. This initiative, wherein a diversity of student leaders are placed in student houses with different themes, affords students the opportunity to be exposed to 'the other' - or students different from themselves in race, gender, home language, religion and so forth - as an experiment in 'experiential learning'. Individual and social formation plays an important role in creating 'networks of becoming', wherein students are to be shaped - by one another, by key speakers that are invited to these houses and by their house mentors into engaged citizens and thought leaders. And indeed, not only is active citizenship promoted and a spirit of engagement fostered within the LLL community, but specifically the formation of friendships is in view here. ${ }^{4}$

Together, the LLLinitiative and the Mandela Rhodes initiative are illustrative of the interplay between individuality and sociability in the formation of young people into thought leaders - and, moreover, friendship as a social strategy in negotiating this interplay within such 'networks of becoming'. However, in the recent series of student protests, such communities of thought leaders - and the very fabric of friendship established and created among such communities as the LLL houses and MR cohorts - have come under scrutiny. Arguably, the rise in student protests is placing communities of thought leaders - such as the LLL initiative at Stellenbosch University and the Mandela Rhodes initiative in Cape Town - under increasing pressure to deal with questions pertaining to the meaning of social engagement and responsibility within the relationships formed within such communities.

3.See https://mandelarhodes.org/the-scholarship/characteristics-sought-in-a-mandelarhodes-scholar/ for more information about the Mandela Rhodes Scholarship, of which the head office is based in Cape Town. The author of this article is a Mandela Rhodes Scholar and is part of the Mandela Rhodes Community.

4.See https://www0.sun.ac.za/IIlbeta/index.php/about-III for more information about the LLL initiative at Stellenbosch University. The author spent 2 years, during her student years, living in the LLL house for Gender Equality and for 2 more years assigned as mentor for the LLL house for Religion and Spirituality. 
An example of the kind of discussions taking place is debates regarding the legacy of Cecil John Rhodes in Africa and South Africa in the light of the \#Rhodesmustfall campaign at the University of Cape Town. A number of Mandela Rhodes scholars go on to become Rhodes scholars as well, and thereby continue to benefit from Rhodes as a benefactor. Yet, for many this creates a moral dilemma: can one want (and, indeed, apply) to be a Mandela Rhodes scholar or Rhodes scholar, and thereby accept the financial benefit that comes with these scholarships while critiquing and resisting the Rhodes legacy - associated as it is with colonialism, exploitation and violence; in short, everything but peace?

These and many other discussions have nowhere near reached their end, but perhaps it is already worth noting that the very fact that these kinds of debates are taking place in the kinds of communities described above creates spaces wherein the networks of friendships and partnerships formed within these communities shape not only those engaged in these discussions, but also become a vital social force within public life and civil society. It is with this dynamic and such exchanges in view that a theological analysis of civic friendship follows below because talking about peacemaking requires talking about friendmaking.

\section{Friendship in civil society}

The study of friendship seems to be receiving increasing scholarly attention, ${ }^{5}$ with published work on the politics of friendship, ${ }^{6}$ philosophy of friendship ${ }^{7}$ and theology of friendship ${ }^{8}$ having appeared recently, including in South Africa. ${ }^{9}$ Among the noteworthy philosophers of friendship - such as Plato, Epicurus, Cicero and Seneca and also Aquinas, Anselm and Montaigne (Vernon 2005:96) - is Aristotle, with his wellknown chapters on friendship in both his The Eudemian Ethics (cf. 2011:112-140) and The Nicomachean Ethics (2009:142-182). In this article, it is specifically 'civic friendship' or friendship in civil society that is considered, especially because Aristotle's theory of friendship would play a formative role in Friedrich Schleiermacher's early ethics (Welker 1999:171-172).

Friendship in civil society would, for philosophers such as Aristotle, be deeply political, in that 'politics was an exercise of friendship' (Vernon 2005:99) - and insofar as friendship involves the exercising of 'political skill' (Aristotle 2011:112; $1234 \mathrm{~b} 24-1234 \mathrm{~b} 25$ ) in the pursuit of the common good, or that

5.'Friendship has not been a significant topic in most modern philosophy or theology with the exception of some significant treatises by such figures as Montaigne and with the exception of some significant treatises by such figures as Montaigne and
Kierkegaard, but in recent years there has been a revival of interest in its theological Kierkegaard, but in recent years there has been a revival of interest in its theological
significance. In part, this is attributable to revived interest in Aristotle's moral philosophy and Aquinas' moral theology. It is also the result of the attempt to do greater justice to the particularities of people's lives, especially in relation to the emotions and embodiment' (Jones 2000:255)

6.See, for instance, Jacques Derrida's The Politics of Friendship (2005).

7.See, for instance, Mark Vernon's The Philosophy of Friendship (2005).

8.See, for instance, Elizabeth Moltmann-Wendel's Rediscovering Friendship (2000). Herein she writes (2000:7) that '[a] theology which develops around friendship, which again experiences God as friend, is interested in salvation and well-being and which again experiences God as friend, is interested in salvation and well-being and in terms of friendship can perhaps also enrich our own capacity for friendship'.

9.See, for instance, Manitza Kotze and Carike Noeth, 'Friendship as a Theological Model: Bonhoeffer, Moltmann and the Trinity' (2017). which is conducive to the common life in which citizens share (Aristotle 2011:128; 1241a18). Moreover, within the political community 'the demands of justice also seem to increase with the intensity of the friendship' (Aristotle 2009:153; 1160a7-1160a8).

A first characteristic of political friendship - which Aristotle also calls 'concord' $(2009: 171 ; 167 b 1)$ or 'friendship in citizenship' (2011:128; 1241a32) - is therefore justice, for 'true friends do not wrong one another' (2011:112; 1234b29). ${ }^{10}$ Stated somewhat differently, the inquiry regarding justice is the inquiry into relationships, or 'how one should treat a friend' (2011:131; 1242a19-21). Indeed, Aristotle regards 'civic justice' as a crucial element of civic friendships because such friendships involve 'not merely friendships, but partnerships between friends' (2011:130; 1242a7-14).

A second characteristic of civic friendship is equality, for 'people are friends when they are on equal terms' (2011:123; 1239a20). This is especially true, for Aristotle, in democracies 'for where citizens are equal they have much in common' (2009:157; 1161b10). And here, as with the characteristic of justice, Aristotle explains that ' $[t]$ he friendship that is based on equality is civic friendship' (2011:132; 1242a22). This involves 'the equal sharing of benefits and burdens' (2011:132; 1242a29-31).

A third characteristic of friendship in civil society is '[w]anting what is good for someone' (Aristotle 2011:136; 1244a22), striving towards the well-being of the other (Aristotle 2011:139; 1245b) and being concerned for the human flourishing of fellow citizens. Citizens are not only to be concerned about one another's lives, but also about one another's well-being and living well (Vernon 2005:100). Consequently, the human flourishing of fellow citizens enriches the whole community, and violence and injustice 'diminishes everyone' (Vernon 2005:100).

In short, within public life 'friendship is a partnership' (Aristotle 2009:181; 1171b33) in that ' $t$ ] he essence of friendship is living together' (p. 181). However, friendship in civic life is not just any kind of partnership - but companionship characterised by justice, equality and flourishing. In other words, the language or 'vocabulary of friendship' may be 'extended more widely' to encompass civic, public and political relationships (Aristotle 2011:124; 1239b6-8).

This seems to be a relevant insight into or primer for understanding Friedrich Schleiermacher's notion of friendship, for it is especially Aristotle's theory of friendship

10.Aristotle would here go to even greater lengths to establish the close relationship between justice and friendship, by claiming that 'justice and friendship are eithe identical or very close to each other' (2011:112; 1234b30-31). The intution that friendship has some relation to justice is also evident in Jürgen Moltmann's thought, wherein he proposes the term 'open friendship' as a description for community of believers who lives openly, with 'open concern and public respect community of believers who lives openly, with 'open concern and public respect for others (Moltmann-Wendel 2000:18). Herein, notes Elizabeth MoltmannWendel (2000:18), friendship would 'become a key notion for a way of thinking in politics and theology'. See also Jürgen Moltmann's chapter on 'open friendship' in his recently published The Living God and the Fullness of Life (2015), which deals with such themes as 'What is Friendship?' (2015:118-119), 'In the Friendship of Jesus' (2015:120-121), 'God's Friends' (2015:122-124) and 'Open Friendship for a Friendlier World' (2015:125-128). 
that would play a formative role in Friedrich Schleiermacher's early ethics (Oberdorfer 1995:94; Welker 1999:171-172) - and particularly as it pertains to his portrayal of friendship in three of his works: (1) Notes on Aristotle (first published 1788; cf. Schleiermacher 1999), (2) Theory of Social Behaviour (first published 1799; cf. Schleiermacher 2006) and (3) Christmas Eve (first published 1827; cf. Schleiermacher 1890). ${ }^{11}$

Yet, as Michael Welker points out (1999:170), the theoretical framework of Schleiermacher's ethics - wherein his thoughts on social behaviour are worked out - is rich and complex, and therefore an exploration of Schleiermacher's understanding of friendship must also acknowledge 'the ways in which diverse, concrete individuality and social and cultural forms hang together'. As such, there are also important differences between Aristotle and Schleiermacher regarding civic friendship, which Bernd Oberdorfer outlines in his book Geselligkeit und Realisierung von Sittlichkeit (1995:94-96).

Among these are their respective approaches to friendship while Aristotle outlines broad types or forms of friendship within the political community, Schleiermacher is more interested in the concretely particular social forms of friendship that function paradigmatically within civil society ${ }^{12}$ (Oberdorfer 1995:95) ${ }^{13}$ Another important difference is the respective functions ascribed to friendship Schleiermacher's description assumes a higher degree of complexity than that of Aristotle in that friendship is normatively shaped by moral feeling and religion in the pursuit of the good life, and not only described by way of a threefold function (pleasure, utility, virtue) as is the case in Aristotle (Oberdorfer 1995:96).

These differences lead to vastly different conclusions in Aristotle and Schleiermacher's respective descriptions of

\begin{abstract}
11.It is important, in this regard, to recall that Friedrich Schleiermacher was involved in establishing the University of Berlin (1810), now called the Humbold University in establishing the University of Berlin (1810), now called the Humbold University of Berlin. Martin Redeker refers in his role as 'professor', 'founder' and 'organiser' of the University of Berlin (1973:4-5). Schleiermacher would play an important role (with such well-known figures as Alexander and Wilhelm von Humboldt) in the formation of the new University of Berlin, which opened in 1810, as part of Prussian renewal. After the publication of his Thoughts on German Universities from a German Viewpoint (1808), Schleiermacher would be appointed to the commission - led by Wilhelm von Humboldt - that would '[lay] down the basic pattern to be followed' for the University. This would reflect Schleiermacher's own convictions about higher learning, including: (1) 'a broad, coherent understanding of learning, philosophically based, in which individual disciplines could be pursued on their own but with equal scientific rigour'; (2) 'a combination of research and ' teaching and (3) a guarantee by the state of freedom in research and teaching' Clements 1987:29). Schleiermacher would be appointed chair of theology, rector of the University (1815) (Clements 1987:29).
\end{abstract}

12.In this essay, Schleiermacher is very careful to distinguish between community, which he defines as 'social gathering[s] that [are] bound and defined by some external purpose' in that 'the participants have something in common', and society, wherein participants 'have nothing in common' but where everything is nonetheless 'reciprocal' (2006:157; footnote 9). Stated somewhat differently, for Schleiermacher ' $[t]$ he true character of a society ... is that there should be a reciprocity that permeates all of its participants but that is also entirely determined and completed by them' (2006:158).

13.'Ist Freundschaft nicht mehr bloßes Steigerungsmoment individueller Versittlichung und gesellschaftlicher Vervollkommnung, so kann sie auch nicht mehr ungebrochen als Keimzelle der (Polis-)Gesellschaft aufgefaßt werden, die bei Aristoteles dergestalt als Grob-Freundschaft zu denken ist. Bei Schleiermacher ist Freundschaft vielmehr eine konkret-partikulare Sozialform, die freilich in dem Sinne paradigmatisch is fur die Gesellschaft insgesamtin dem daß in ihr diejenigen Wahrnehmungskriterien und Beurteilungsstandards bereits in Geltung stehen, die in abgestufter und den jeweiligen Kontexten angemessener Weise in allen in abgestufter und den jeweiligen Kontexten angemessene
Bereichen der Gesellschaft gelten sollen' (Oberdorfer 1995:95). friendship, in that Schleiermacher works within the ambit of Aristotelian ethics (that posits that friendship is a complex social phenomenon), but extends his reflection beyond types of friendship to the myriad of individual, particular actions that take place within a community (Oberdorfer 1995:96). In his 'Notes on Aristotle', Schleiermacher argues that 'sociable connections' play an important role in shaping the texture of a society that values justice, equality and human flourishing - he writes that 'a more intimate interest' in a fellow human being, a stranger even!, may encourage a person to 'perform a whole series of actions for his [sic] optimal welfare, and thereby alter his [sic] entire condition in an advantageous manner' (Schleiermacher 1999:166).

In his 'Theory of Social Behaviour', Schleiermacher describes such a series of actions not as a set of prescriptions, but as patterns of a game (or 'Mustern des Spiels'; Schleiermacher 1984:166). The play consists of 'a multiplicity of actions, both of one's own and of others' (Welker 1999:173) that takes place within 'complex social relations' (Welker 1999:173). The individual, concretely particular behaviour of a person that is enacted to the benefit of another person (particularly those disadvantaged by or within a society) cannot be regarded by itself, however, lest it gives rise to 'egotistic feelings' (Schleiermacher 1999:166) or 'condescension' (Welker 1999:173).

As such it is only through embedding such actions in an 'open society' that the texture of such a society may be shaped towards the common good (Welker 1999:173) - or, at the very least, 'look to it that the common good sustains no damage', writes Schleiermacher (2006:154). ${ }^{14}$ Herein friendship itself may have formative power in shaping societies - even more so if '[f]riendship could be a form of society' (Vernon 2005:112). Stated somewhat differently, friendship may represent a new society whose social texture is defined by justice, equality and the flourishing of all human beings.

\section{The fabric of friendship}

If we, as members of a civil society, possess an assemblage of goods and enjoy an assemblage of happinesses in which we never would have come to have a part without that society, there are, by contrast, others who as citizens enjoy less of what is good and have fewer means to happiness than they would have had simply as human beings. We therefore owe it to them to take a part of the excess with which we have been favoured and to employ it for the improvement of the condition of these unfortunate persons, who have become the victims of a destiny that could just as easily have been our own (cf. Schleiermacher 1999:165).

14. Here Schleiermacher is quite realistic about human beings: he writes in his Notes that 'human beings are hard, inflexible things' (1999:166) and in his Essay that 'one can despair everywhere at the awkwardness and malice of individuals' (2006:154). As such 'there is much to eliminate, a good deal to alter' and 'every individual' is As such 'there is much to eliminate, a good deal to alter' and 'every individual' is
required to adjust 'his or her behavior in accordance with that common goal' required to
$(2006: 154)$. 
Friedrich Schleiermacher's philosophical ethics, and particularly the young Schleiermacher's notes on Aristotle and essay on a theory of sociable behaviour, may further contribute to a reflection on the self-in-relation. For Schleiermacher, together the individual self and the public social self would contribute to an understanding of human beings as 'social individuals' (Oberdorfer 1996:430-434). This means, for Schleiermacher (2006:162), that sociability involves (1) a series of individual actions and (2) selflimitation for the sake of other individuals. ${ }^{15}$ Yet, this does not mean that the application or implications of civic friendship is by any means simple or straightforward. As Mark Vernon points out (2005):

[The Aristotelian] quality of civic connectedness is different to, say, the modern concern for the human rights of others. And it is deeper than, say, the groundswells of sentiment evoked by mass media. The goodwill Aristotle wants people to embrace looks to other citizens' spiritual wellbeing alongside material success, an aspiration that perhaps inevitably reaches beyond the expectations people have (or would want) from a modern plural democracy. (p. 100)

It is, with this critique in mind, therefore also worth considering Schleiermacher's Christmas Eve (1827), 'the little work of the master' that has become 'precious jewel of our modern theological literature' (William Hastie in the preface to Christmas Eve; 1890:xi). In Christmas Eve, friendship is a central part of the story - and indeed, this work was itself written as a surprise Christmas gift to his friends (Tice 1967:100).

This fictitious story spans at least three interwoven themes: music, childhood and women (Gerrish 1984:14-15), but to these could be added other important and prominent themes, such as friendship (William Hastie in Schleiermacher 1890:75). And of course we know that friendship played an important role for Schleiermacher, not only in his Christmas Eve, but in all of his life (Tice 1967:103). Schleiermacher 'is known to have possessed an extraordinary capacity for friendship all his life' and was interested in the personal characters, diversity of human personalities and many different people that he met (Tice 1967:103). It is therefore unsurprising that his Christmas Eve would be set in the midst of 'an assembly of friends', which is marked by a collective mood of 'pure cheerfulness', 'freshly stirred love', 'joy', 'gladness' and 'playsome childlikeness' (Schleiermacher 1890:41).

In this story, Schleiermacher illustrates, within the various social relationships between individual characters, the fabric of friendship that he describes in his earlier Notes (1788) and

15. He describes this as the 'tone' of society, or 'the character of society' (that which is described as texture or fabric or fibre in this paper) (2006:164). The tone or texture of society is of great importance to Schleiermacher in his Essay because individuals are to 'observe the tone of the society' and therein 'be guided and limited by that society' (2006:164). This does not mean, however, that individuals must agree on
everything or that anyone should 'be timid about his or her own distinct manner' everything or that anyone should 'be timid about his or her own distinct manner'
(2006:164) - quite the opposite, for Schleiermacher, for he regards it as 'essential (2006:164) - quite the opposite, for Schleiermacher, for he regards it as 'essential
to the perfection of a society that its members diverge from one another in their to the perfection of a society that its members diverge from one another in their
opinion on the subject and in their manner of dealing with it in as manifold ways as possible' (2006:165). This is important because it provide the only way in which possible' (2006:165). This is important because it provide the only way in which
'the subject [can] be exhausted in regard to sociability, and the character of the 'the subject [can] be exhausted in regard to socia
society [can be] entirely developed' (2006:165).
Essay (1799). However, the question may be raised as to whether Schleiermacher's portrayal of the fabric of friendship, or the interplay between individuality and sociability, is robust enough to address protesting societies characterised as they are by resistance against injustice, inequality and corruption. In other words, which roles may such an understanding of friendship play in a time of protest, wherein the ideals of greater social cohesion within communities and the integrity of robust, critical dialogue among diverse social individuals are contested? Considered together, these three works may make it possible to offer three preliminary remarks on the portrayal of friendship that may emerge for a time of protest.

Firstly, a discussion on 'networks of becoming', 'sociability' and 'individuality', and indeed 'the fabric of friendship' needs to take the quotidian seriously. ${ }^{16}$ Schleiermacher does not deny the givenness of inequality in society, nor that there are those who are privileged or 'favored with excess' as well as those who are the 'victims of destiny' (Schleiermacher 1999:165). Instead, he is realistic about the fact that there are citizens who 'possess an assemblage of goods' and who 'enjoy an assemblage of happinesses', as well as citizens who 'enjoy less of what is good' and who 'have fewer means to happiness' (1999:165).

It is exactly such a consciousness of privilege - of what Schleiermacher calls 'undeserved advantage' (1999:165) that relativises attempts to justify systemic inequality, points to the beginnings of social critique and social activism, and accepts the negative mystery of theodicy. Why are there those favoured with excess and those victimised by destiny? Schleiermacher does not say. He simply does not go beyond acknowledging that members of civil society have different modes of access to civil goods and happinesses that such a society offers.

Secondly, a discussion on 'networks of becoming' needs to take the social networks and 'sociable connections' - or sociability, or social behaviour, or social conduct - seriously. Exactly because individuals - even good, dutiful, beneficent individuals who help 'disadvantaged human beings' - affect each other mutually (Schleiermacher 2006:157-158), this should lead to the acknowledgment that individuals are embedded in 'complex social relations' (Welker 1999:173). ${ }^{17}$

\footnotetext{
16.This involves recognising the givenness of society, "which is a necessary preprequisite for becoming a society' (Schleiermacher 2006:160). As such, the
communicative responsibility - or language 'appropriate to sociable communicative responsibility - or language 'appropriate to sociable
communication' $(2006: 160)$ forms part of 'the course of social intercourse' communication' (2006:160) forms part of 'the course of social intercourse'
(2006:160).

17.It is therefore important to acknowledge that societies are 'cultural and social environment that are shaped by us and by our fellow human beings' (Welker 1999:172, 1983). However, as important as it is for individuals to 'help those weakened by this environment' that all of us continually help to create (Welker 1999:172), it is not enough - argues Schleiermacher. Of course those who have been favoured by society, with more of what is good and more means to happiness, have a duty towards those who have been disadvantaged by this self-same society have a duty towards those who have been disadvantaged by this self-same society (Schleiermacher 1999:165). Yet, Schleiermacher warns that individual sentiment, compassion and beneficence is not strong enough to excite us to those actions in the future' (1999:165). It is not enough because charity, wherein a person 'condescends to such an extent to be the author of another's happiness' is still, 'after all, 'acting according to his own will' (Schleiermacher 1999:173) and no socially embedded in a fabric of friendship that may influence others to act in a benevolent manner towards disadvantaged human beings (Welker 1999:173).
} 
Yet, that which individuals contribute is (Schleiermacher 2006):

$[H]$ is or her very individuality or uniqueness, and the free play of thoughts and feelings, which should constitute that individual's activity in the society, is founded solely in this uniqueness. (p. 161)

For Schleiermacher, this means that 'everything is to be reciprocal' (2006:159), which requires of societies to make possible the free play of thoughts and feelings by means of which all members excite and animate one another' (2006:159). Sociality therefore requires not heroic, isolated, individual acts of beneficence, but rather reciprocity: ${ }^{19}$ the 'long[ing] for connection with like-minded beings' and the sharing of power that 'open[s] a wider field for moral action' (Schleiermacher 1999:168). ${ }^{20}$

Thirdly, a discussion on 'networks of becoming' needs to acknowledge the necessity of 'hopes for a better world' (Schleiermacher 1999:168). Indeed, that which 'can really nourish sociable sentiments' is that which 'goes beyond the system of its ideas and acts in accordance with an alien purpose' (Schleiermacher 1999:166). For Schleiermacher, the motivation to contribute to the common good cannot be limited to a realism regarding the quotidian or to a shared, social concern for those disadvantaged by and within society. It requires not only an acknowledgment of the human dignity of all citizens (however enthusiastically or begrudgingly this may be!), but an altogether deeper concern for the human flourishing of my fellow citizen. For Schleiermacher, this means 'perform[ing] a whole series of actions for his [sic] optimal welfare' (1999:166) and 'for their optimal benefit' (1999:167).

The motivation for going beyond the minimum actions required by morality or even sociality is the concern to

18.This is a key insight that determines what Schleiermacher means by the interplay between individuality and sociability. He writes that 'someone is not a member of a society by virtue or possessing this or that quality or piece of knowledge or belonging to a particular class' (2006:161). It follows that to '[d]eprive that person belonging to a particular class' (2006:161). It follows that to ' $[d]$ eprive that person
of some part of his [sic] principles, opinions, mode of expression, and behavior and of some part of his [sic] principles, opinions, mode of expression, and behavior and
his individuality is lost and he is no longer capable of presenting to us his own views his individuality is lost and he
of mankind [sic]' (2006:161).

19.This has to do with the very purpose of society, for Schleiermacher (2006:158159): 'If we take a look at the purpose that is to be achieved by means of this thoroughgoing reciprocity, then it becomes patently obvious, as a result of the predicate of freedom itself, that one should not even speak of a single and determined purpose because the latter determines and limits activity according to material and objective rules. No finite action is to be carried out communally, no undertakings completed in unison, no insight attained methodically. The purpose of society is certainly not to be thought of as lying outside of itself; each individual's of society is certainly not to be thought of as lying outside of itself; each individual's effect should be on the activity of the rest, and the activity of each individual should be his or her influence on the others. However, there is not other way to influence a free being other than to stimulate it to self-motivated activity and to offer it an object ... in other words, it can aim at nothing other than the free play of thoughts and feelings by means of which all members excite and animate one
another. Reciprocity thus reflects upon and completes itself: the concept of another. Reciprocity thus reflects upon and completes
reciprocity also determines the entire nature of society'.

20.This does also, however, not mean that the individuality should be collapsed into sociability. Rather, it is the concrete particularity of human beings in society - or both the givenness of individuality and sociability - that must be maintained. And indeed, '[a]s a finite being, every individual has his or her definitive sphere in which he or she can think and act... The sphere of one individual is not fully that of another, just as certainly as he or she is not that other individual, and everyone this includes each and every member of society - has something in his or her spehere that is not included in that of others' (Schleiermacher 2006:160). To this spehere that is not included in that of others' (Schleiermacher 2006:160). To this end, and as a means to maintain 'individual differences without thereby necessarily surrendering the interest in what is universal and the search for commonality' Michael Welker suggests the concept 'polyindividuality' to distinguish individuality from 'modern individualism' ('with its assumptions of homogeneity and of abstract equality') (1999:74). This, then, points toward 'free sociability' - which Schleiermacher describes as 'neither fettered nor determined by any external end' (2006:153). 'promote God's glorification' (Schleiermacher 1999:166). Herein Schleiermacher acknowledges not only the sociable connections between human individuals, but that human beings form part of an even broader community - a community that includes the divine communion. As such, individuals '[acquire] a share in others' relations to God' when the conditions, actions and environment that is required for the flourishing of my fellow human being are anticipated and, indeed, realised.

Together these three remarks offer a portrayal of the fabric of friendship that may play an important role in forming meaningful relationships, having meaningful discussion and debate, and playing a meaningful role within society in a time of protest. This is the role that the African public theologian Russel Botman would have in mind when describing students as 'agents of hope in Africa', and the role of universities - and Stellenbosch University in particular as potential hosting spaces that cultivate such student communities.

This is also the role that a network such as the Mandela Rhodes Community may have to play in such times of conflict and contestation of meaningful relationships. Without friendship there can be no peace.

However, the negotiation between individuality and sociability does not appear to be a sterile, cold or disengaged activity for Friedrich Schleiermacher. Without 'the moral feeling always summoning him [sic] ... to engage in real action' (1999:168), or the 'long[ing] for a connection with a being whom he $[\mathrm{sic}]$ cannot regard otherwise than from the perspective of equality' (1999:167), or the manifold ways in which 'people stimulate one another' (Schleiermacher 2006:159), or indeed 'loving human beings' (Schleiermacher 1999:166) - reciprocity and the duty of beneficence towards fellow citizens become unsustainable, superficial and inauthentic.

Instead, it would appear as if the interplay between individuality and sociability is 'the play of all sorts of enchantments' (1999:167), wherein an individual 'will find that his own happiness ... is that much more beautiful when others contribute to it according to his wishes' (1999:167). This, writes Schleiermacher (1999:167), produces 'those mutual sentiments that are the ground of all sociability and all connections of friendship'. Friendship requires nothing less than the anticipation of my neighbours' flourishing, and working towards realising the conditions that may make their living good and full lives possible. It is in such a society that the social texture of civil life can be defined by justice, equality, peace - in short, the flourishing of all human beings.

\section{Conclusion}

Friendships that are not on a straightforward footing leave room for many recriminations, and it is not easy to see what is just, because it is not easy to measure by a single standard 
things that are not straightforward (Aristotle 2011:134; 1243b14-17).

Friedrich Schleiermacher's interest in human experience and relationships between social individuals may provide a helpful way of thinking about friendships in a time of protests, with its high regard for feeling and experience, for behaviour and individuality, for sociability and relationships. For, surely, the question of the fabric of friendship therein becomes a question of the kinds of engagement required by engaged citizens, as those who are concerned about the flourishing of all human beings. Moreover, the 'fabric of friendship' may point to exactly the kind of reflection needed in a time of protest, wherein relationships of meaning are tested and the interaction between the individual and social selves of engaged citizens demand attention.

This does not mean, however, that it may be simple or straightforward to negotiate what such friendship, or such justice, or such equality, or such peace, or even a commitment to human flourishing, may mean in societies where the texture of sociality and social cohesion is under duress. Acknowledging the importance of 'the finer feeling of friendship', the need for sociable connections and the desire for the other's well-being therefore require imagination.

Perhaps the 'obligation to perform beneficent actions' as part of the fulfillment of 'duty to a higher degree' (Schleiermacher 1999:166) does not only rest in the consolation that 'the frail old man' that Schleiermacher speaks of is surrounded by his family and friends, but also restlessness; not only hope but also anticipation; and not only enchantment but also imagination. For if friendship is to mean anything, anything at all, it should work for peace - meaning, it should be restless in situations of injustice and inequality; it should be able to anticipate the conditions required for the human flourishing of vulnerable citizens and it should be imaginative in working towards a better world for all human beings.

Eben, because you have written several articles on peace, ${ }^{21} \mathrm{I}$ would like to suggest that friendship has some role to play in our theological considerations of peacebuilding and peacemaking. Friendmaking involves peacemaking and peacemaking involves friendmaking. And because this is your festschrift, I should probably conclude this article with Jesus' own words (I can already hear you say!): Blessed are the peacemakers, for they shall be called children of God.

\section{Acknowledgements}

This article was presented at the Schleiermacher Group of the American Academy of Religion in San Antonio (19-22 November 2016), with the theme 'Networks of Becoming: Individuality, Friendship, and Forms of Social Life'.

21.A small sample of Eben Scheffler's publications on peacebuilding and peacemakin includes 'Reflecting on Jesus' teaching on forgiveness from a positive psychological (Scher experience (Scheffler 2015a), 'The Historical Jesus as Peacemaker between udaism, Christianity, and Islam' (Scheffler 2015b) and 'The Historical Jesus and (Non-)Violence: A Contemporary Challenge' (Scheffler 2016). I suspect that would be important to Eben to note that all of these titles - at least those cited here! - revolve around the role of the historical Jesus as enabler and maker of the peace.

\section{Competing interests}

The author has declared that no competing interest exists.

\section{Author(s) contributions}

I declare that I am the sole author of this research article.

\section{Ethical consideration}

This article followed all ethical standards for a research without direct contact with human or animal subjects.

\section{Funding information}

This research received no specific grant from any funding agency in the public, commercial or not-for-profit sectors.

\section{Data availability statement}

Data sharing is not applicable to this article as no new data were created or analysed in this study.

\section{Disclaimer}

The views and opinions expressed in this article are those of the author and do not necessarily reflect the official policy or position of any affiliated agency of the author.

\section{References}

Aristotle, 2009, The Nicomachean ethics (Oxford World's Classics), L. Brown (ed.), transl. D. Ross, Oxford University Press, Oxford.

Aristotle, 2011, The Eudemian ethics, transl. A. Kenny, Oxford World's Classics, Oxford University Press, Oxford.

Botman, H.R., 1993, 'Discipleship as transformation? Towards a theology of transformation', Doctoral dissertation, University of the Western Cape, Cape Town.

Botman, H.R., 2004, 'Turning the tide of the city: An ecumenical vision of hope', Nederduitse Gereformeerde Teologiese Tydskrif 45(3\&4), 508-517.

Clements, K., 1987, Friedrich Schleiermacher. Pioneer of modern theology, Collins Publishers, London.

Derrida, J., 2005, The politics of friendship, transl. G. Collins, Verso Press, London.

Ford, D.F., 2017, 'The future of theology at a public university', Verbum et Ecclesia 38(1), a1807. https://doi.org/10.4102/ve.v38i1.1807

Gerrish, B., 1984, A prince of the Church: Schleiermacher and the beginnings of modern theology, SCM Press, London.

Jones, G.L., 2000, 'Friendship', in A. Hastings, A. Mason \& H. Pyper (eds.), The Oxford companion to Christian thought, pp. 254-255, Oxford University Press, Oxford.

Kelsey, D.H., 2009, 'Theology in the University: Once more, with feeling', Modern Theology 25(2), 315-327. https://doi.org/10.1111/j.1468-0025.2008. 01521.x

Kotze, M. \& Noeth, C., 2019, 'Friendship as a theological model: Bonhoeffer, Moltmann and the Trinity', In die Skriflig 53(1), a2333. https://doi.org/10.4102/ ids.v53i1.2333

Moltmann, J., 2015, The living God and the fullness of life, transl. M. Kohl, Westminster John Knox Press, Louisville, KY.

Moltmann-Wendel, E., 2000, Rediscovering friendship, SCM Press, London.

Oberdorfer, B., 1995, Geselligkeit und Realisierung von Sittlichkeit: Die Theorieentwicklung Friedrich Schleiermachers bis 1799, Walter de Gruyter, Berlin.

Oberdorfer, B., 1996, 'Von der Freundschaft zur Geselligkeit: Leitkonfigurationen der Theorieentwicklung des jungen Schleiermacher bis zu den "Reden"', Evangelische Theologie 56, 415-434. https://doi.org/10.14315/evth-1996-0503

Redeker, M., 1973, Schleiermacher: Life and thought, transl. J. Wallhausser, Fortress Press, Philadelphia, PA.

Scheffler, E., 2015a, 'Reflecting on Jesus' teaching on forgiveness from a positive psychological experience', HTS Teologiese Studies/Theological Studies 70(1), Art. \#2982, 10 pages. https://doi.org/10.4102/hts.v70i1.2982 
Scheffler, E., 2015b, 'The historical Jesus as peacemaker between Judaism, Christianity and Islam', Neotestamentica 49(2), 261-296. https://doi.org/10.1353/ neo.2016.0002

Scheffler, E., 2016, 'The historical Jesus and (non-)violence: A contemporary challenge', in J. Hunter \& J. Kügler (eds.), The Bible and violence in Africa, pp. 91-115, University of Bamberg Press, Bamberg.

Schleiermacher, F., 1890, Christmas eve: A dialogue on the celebration of Christmas, transl. W. Hastie, T \& T Clark, Berlin.

Schleiermacher, F., 1984, 'Versuch einder Theorie des geselligen Betragens', in G. Meckenstock (ed.), Kritische Gesamtausgabe (KGA) I/2: Schriften aus der Berliner Zeit (1796-1799), pp. 163-184, Walter de Gruyter, Berlin.

Schleiermacher, F., 1999, 'Notes on Aristotle: Nicomachean Ethics 8-9', transl.J.F. Hoffmeyer, Theology Today 56(2), 164-168. https://doi.org/10.1177/004057369905600203
Schleiermacher, F., 2006, Friedrich Schleiermacher's essay on a theory of social behaviour (1799): A contextual interpretation, pp. 153-176, transl. P.L. Foley, Edwin Mellen Press, New York.

Tice, T.N., 1967, 'Schleiermacher's interpretation of Christmas: "Christmas Eve," "The Christian Faith," and the Christmas Sermons', The Journal of Religion 47(2), 100-126. https://doi.org/10.1086/486011

Vernon, M., 2005, The philosophy of friendship, Palgrave Press, London.

Welker, M., 1983, 'Friedrich Daniel Ernst Schleiermacher: Universalisierung von Humanität', in J. Speck (ed.), Grundprobleme der großen Philosophen Philosophie der Neuzeit III, pp. 9-45, UTB, Stuttgart.

Welker, M., 1999, "'We live deeper than we think": The genius of Schleiermacher's earliest ethics', Theology Today 56(2), 169-179. https://doi.org/10.1177/ 004057369905600204 